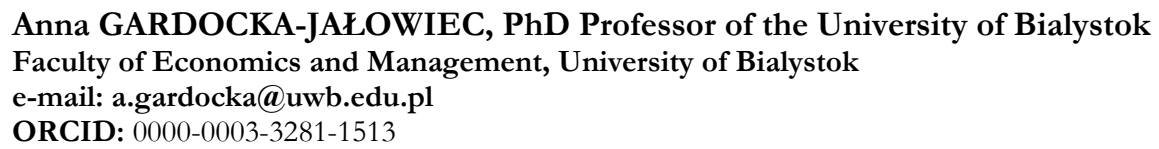

Katarzyna SZALONKA, PhD, adjunct of the Univeristy of Wroclaw

Faculty of Law, Administration and Economics, University of Wroclaw

e-mail: katarzyna.szalonka@uwr.edu.pl

ORCID: 0000-0001-7290-6408

Piotr STAŃCZYK, PhD, adjunct of the Wroclaw University of Economic

Department of Economic Sciences, Wroclaw University of Economics

e-mail: piotr.stanczyk@ue.wroc.pl

ORCID: 0000-0003-0124-2936

DOI: $10.15290 /$ oes.2018.04.94.20

\title{
THE DETERMINANTS OF SHOPPING PLACE SELECTION IN POLAND - THE SURVEY RESULTS
}

\begin{abstract}
Summary
Goal - The aim of the empirical research using the electronic survey questionnaire was to identify the determinants of consumers' behavior on the market on the basis of the type, place and frequency of purchasing goods that satisfy the basic needs.

Research methodology - There were presented results of the survey conducted online $(n=482)$ in Poland. The character of the sample was random and representative.

Score - The research showed that $97 \%$ of respondents do shopping at least once a week, whereas $33 \%$ of surveyed individuals go shopping every day. There was observed statistically essential dependence of preferences related to the shopping frequency on the age and the character of the town and region. The selection of the shopping place was, in statistic terms, influenced by the region - voivodeship (except for coffee/tea) and by the character of the town (except for bakery products and sweet baked goods) or the level of incomes (chiefly with regards to the purchase of cold meats and coffee/tea).
\end{abstract}

Key words: consumers' behaviors, shopping frequency, shopping place, determinants of shopping, consumption in Poland

JEL classification: D12, D15 


\section{Introduction}

The aim of the empirical research using the electronic survey questionnaire was to identify the determinants of consumers' behavior on the market on the basis of the type ${ }^{1}$, place $^{2}$ and frequency ${ }^{3}$ of purchasing goods that satisfy the basic needs. ${ }^{4}$ The necessity to conform to certain work volume did not enable making a precise analysis of all the essential factors included in the survey questionnaire. The questionnaire was limited to analyze only the basic factors, i.e. the age of the respondent, the number of persons in a household, the town's character (village, a town with less than 100000 inhabitants, a town with 100 000-500 000 inhabitants, and a city with more than 500000 inhabitants), the region of residence (voivodeship), the place of residence - voivodeship, the average monthly spending on shopping in a household in general.

Owing to the adopted methodological assumptions of the research, the statistical analysis is focused on consumers. The research comprised the group of 482 respondents who do shopping in Poland.

\section{Literature review}

The knowledge of the consumer's decisions is trade basis - a consumer is an active (not passive) participant of market interactions [Chmielak, 2015]. The preferences, expectations, satisfaction and all the other emotional states of a purchaser set the direction and scale of the activities undertaken (at present and in the future) by trade companies [Anselmsson, 2006; Rajagopal, 2011]. The selection of the place of doing shopping and its frequency are of considerable importance in the times of the purchaser's market and considerably stronger necessity to build efficient competitive advantage [Carpenter, Moore, 2006]. The usefulness of market research in this degree increases proportionally to the increase of the uncertainty of activities undertaken by trade entities. The uncertainty increases simultaneously with the expansion of outlet and the assortment of offered goods [Jaciow et al., 2013, p. 26; Kaczmarczyk, 2003, p. 17; Kamran-Disfani et al., 2017; Mitchell, 1992]. Additionally, there are observed changes in the shopping behaviors of purchasers [Bell et al., 2011; Nilsson et al., 2017]. The changing needs and preferences of consumers are accompanied by the multitude and diversity of the sources of information regarding

1 Types: in gourmet groceries, in discount stores (Biedronka, Lidl, Aldi, Netto, etc.), in hypermarkets (Tesco, Auchan, Carrefour, ...), in stores located near home (local one or Żabka), in ecological stores, in Internet stores, in supermarkets (e.g. Intermarche, Piotr i Pawel).

2 Place - The research was conducted mainly in two voivodeships - Dolnoślaskie and Podlaskie and also for controlling purposes in all remaining ones by using the principle: $50 \%$ - the indicated two voivodeships for comparison and $50 \%$ - other voivodeships.

3 Type: once a month, a few times a month, once a year, twice a year, a few times a year, occasionally, I never buy.

4 Type: food products; housewares /RTV; clothes, underwear, shoes, bags /handbags, books, jewelry, medication, domestic detergents, cosmetics. 
the products and change in the trade structure [Kim, Lee, 2008]. In the shopping process there are listed not only factors that are taken into consideration by consumers, but there is included also the place where shopping is done [Angowski, Domańska, 2015, p. 386; Caitlin et al., 2017; Hill, 1988; Morganosky, Cude, 2000; Ruff 2016; Urban, Michałowska, 2013, p. 136; Urban, Michałowska, 2013a, p. 109]. The selection of the place of purchasing goods constitutes one of the stages of the purchasing process. At the beginning of this process there arises the general problem of selecting the type of a shop, the subsequent stage is related to seeking information and later on alternatives are analyzed and the final decision is made [Angowski, Domańska, 2015, p. 387; Gensler et al., 2012, p. 988; Kamran-Disfania et al., 2017]. Therefore, one may assume that the purchaser assesses the possible purchase places while taking into consideration, among others: the accessibility of products, the time devoted to shopping and the price [Jacobs et al., 2010, pp. 169171].

The changes that have occurred in recent years in the trade sector in Poland contributed to the fact that consumers have larger possibilities as regards the place of doing shopping. They may select: marketplaces, food stores, supermarkets and hypermarkets, discount stores, specialist stores and Internet stores. In recent years in Poland there has been observed dynamic growth of the network of discount stores. At the end of 2016 their number was estimated as more than 3.800. In comparison with 2015 there were 116 stores more stores. Discount stores compete with other trade forms by offering better prices. The price is one of the basic factors that are taken into account during the purchase of food [Kosicka-Gębska et al., 2011].

In the development of the trade sector considerable importance is also attached to the shopping frequency of consumers. In accordance with the report prepared by Pentor, Polish consumers more willingly do shopping ad hoc - they spread shopping over time - they do shopping on various week days (yet the dominating role of Friday and Saturday is still observed), seek savings in a larger number of shops by appreciating smaller stores [Zachowania zakupowe..., 2010]. There are more people who devote little time for doing shopping (e.g. one hour a week). They do their everyday shopping in the stores located in the vicinity of their home when the commuting time does not exceed 10 minutes [Zachowania zakupowe..., 2010].

Consumers' preferences regarding, among others, the shopping place and frequency determine the selection of the location and assortment policy by trade companies [Szwacka-Salmonowicz, 2003, pp. 34, 87].

\section{Data collection and methodology}

\subsection{Data collection}

The presentation of analyzed issues is based on the results of the survey conducted in February 2018 in all voivodeships. The survey had anonymous character. The selection of respondents was random, but still it was controlled in terms of the 
age, the place of residence of respondents, the size of a household. For the needs of this statistical analysis there were selected 482 properly filled in questionnaires, i.e. 3$4 \%$ respondents from 14 voivodeships, which constituted $50 \%$ of surveyed individuals and $50 \%$ of answers given by people living in Dolnośląskie (133 individuals) and Podlaskie (133 individuals) voivodeships in order to make a comparative analysis. In the analyzed group every third respondent represented a household composed of 2 persons, every fourth respondent was from a household composed of 4 persons. One half of respondents comprised people who are older than 29 years old, whereas the second half included persons in the age from 30 to more than 70 years old.

The empirical research was realized thanks to the technique of a survey while using an electronic survey questionnaire that is available online.

The survey questionnaire included two basic questions that described:

- the frequency of doing shopping as regards food products, housewares/RTV, clothes and underwear, shoes, bags, jewelry, books, medication, domestic detergents, cosmetics and other items necessary for man's existence (symb. $\mathrm{X}_{\mathrm{a} 1} ; \mathrm{X}_{\mathrm{a} 2}, \ldots \mathrm{X}_{\mathrm{a} 12}$, for the mentioned 12 groups of goods); the range of answers comprised, among others: every day, a few times a week, once a month, a few times a month, once a year, twice a year, a few times a year, occasionally, never;

- the place of most frequent purchases of: bakery products, cold meats, sweets, dairy, vegetables and fruits, baked sweet products, coffee and tea (symb. variable $\mathrm{X}_{\mathrm{b} 1} \ldots \mathrm{X}_{\mathrm{b} 7}$; for the 7 listed groups of goods); the range of answers comprised, among others: in gourmet groceries, in discount stores (Biedronka, Lidl, Aldi, Netto etc.), in hypermarkets (Tesco, Auchan, Carrefour, ...), in the stores located near home (a local store or Żabka), in ecological stores, in Internet stores, in supermarkets (e.g. Intermarche, Piotr i Pawell);

- the main determinants of the purchase location.

\subsection{Methodology}

Statistical methods included in this part of the paper are based chiefly on the basic statistical methods that could be employed while using the available empirical material. Owing to the fact that in the majority of cases the analyzed characteristics had quality character, the most frequent description concerned the structure, intensity of a certain process, the comparisons of structures for various subpopulations (in accordance with the division into a town - village or division depending on the sex or age).

In order to specify whether, owing to selected classification criteria of the analyzed group of consumers, the selected qualitative variables: $X$ (possessing the categories $\left.X_{1}, X_{2}, \ldots X_{r}\right)$ i $Y$ (with categories $Y_{1}, Y_{2}, \ldots Y_{s}$ ) are self-reliant, there were constructed proper contingency tables (also known as a cross tabulation or crosstab) with $r$ lines and $s$ columns and there were used basic measures of independence 
[Aczel, Sounderpandian, 2017, pp. 747-760; Szreder, 2010, pp. 170-175]. The lines in such table correspond to the levels of one classification category - the value of variable $X$ (e.g. $\mathrm{X}_{\mathrm{A}}$ - the frequency of purchases of selected groups of goods ${ }^{5}$ and $\mathrm{X}_{\mathrm{B}}-$ the place of the most frequent purchase of the selected groups of goods $\left.{ }^{6}\right)$, and columns - second classification category - the values of variable $Y$ (e.g. $Y_{1}-$ age group, $\mathrm{Y}_{2}$ - the character of the town of residence, $\mathrm{Y}_{3}$ - the number of persons in a household, $Y_{4}-a$ voivodeship and $Y_{5}$ - the average monthly expenditures on shopping). The inside of the contingency table denote the numbers of $n_{i j}$ these elements of our $n$ - element sample $(n=482)$, where the values of both characteristics belonged to $i$-line of $j$ column. To sum up, in lines and columns of most numbers $n_{i j}$ there are obtained marginal values, i.e. for $i$ line it amounts to:

$$
\begin{gathered}
n_{i \bullet}=\sum_{j=1}^{s} n_{i j} \text { for } i=1,2, \ldots, r \\
n_{\bullet j}=\sum_{i=1}^{r} n_{i j} \text { and for } j \text { column: for } j=1,2, \ldots, s
\end{gathered}
$$

In order to verify the truthfulness of the hypotheses regarding the independence of classification variables $X$ and $Y$ (at the adopted relevance level $\alpha=0.05$ ), there was offered the most frequently used independence test $\chi^{2}$, which is based on the possibility to calculate the anticipated numbers - theoretical in contingency table (which means numbers that would be expected if there was dependence between the variables).

On the basis of data from the sample there was specified the value of test statistics:

$$
\chi^{2}=\sum_{i=1}^{r} \sum_{j=1}^{s} \frac{\left(n_{i j}-n \cdot p_{i j}\right)^{2}}{n \cdot p_{i j}}
$$

By using statistic packages the decision regarding either rejection/acceptance of the zero hypothesis was made on the basis of the probability value $p$ ( $p$-value) calculated (on the basis of sample data) for the specific value of test statistics $\chi^{2}$. If $p$-value was lower or the same as the adopted relevance level $\alpha=0,05$, the hypothesis regarding independence was rejected.

Apart from checking whether the selected variables are dependent it was interesting to specify also how strong the dependence was. In practice, the majority of

5 Food products; housewares/RTV; clothes, underwear, shoes, bags, books, jewelry, medication, domestic detergents and cosmetics

6 Bakery products, cold meats, sweets, dairy, vegetables and fruits, sweet baked products / sweets, coffee / tea. 
the existing dependence measures (correlation measures) of quality features are constructed on the values of statistics $\chi^{2}$. The most frequently used coefficient was $\varphi$-Yule coefficient in the following form:

$$
\varphi=\sqrt{\frac{\chi^{2}}{n}}
$$

The coefficient (4) adopts the values from 0 to 1 . If the values of the coefficient oscillated around 0 , it showed the independence of values $\mathrm{X}$ and $\mathrm{Y}$ (the lack of connection between the variables). When the value of a certain coefficient was closer to 1 , the stronger was the dependence between the analyzed characteristics X and Y.7

The calculations were made using Excel spreadsheet program and the statistical package STATISTICA.

\section{Results}

In accordance with the expectations (knowledge of the needs and the frequency of purchases of basic consumption goods) the data obtained from the survey research showed that most frequent shopping (at least once a week) is done in case of food products $-97 \%$ of the total number of respondents (also every day - approx. $1 / 3$ of respondents).

At the most a few times a month- there were purchased mainly domestic detergents, cosmetics and clothes, whereas at the most a few times a year - chiefly shoes and underwear. The vast majority of respondents purchased jewelry occasionally (comp. table 1).

7 In case of coefficient $\varphi$ - Yule, if $\mathrm{r}>2$ and $\mathrm{s}-$ optional, $\varphi$ may be slightly higher than 1 . 
TABLE 1

The percentage structure of the frequency of purchases of the analyzed groups of goods

\begin{tabular}{|l|c|c|c|c|c|c|}
\hline \multirow{2}{*}{$\begin{array}{c}\text { Selected groups of } \\
\text { goods }\end{array}$} & \multicolumn{6}{|c|}{ The frequency of purchases } \\
\cline { 2 - 7 } & $\begin{array}{c}\text { Every } \\
\text { day }\end{array}$ & $\begin{array}{c}\text { 1-a few } \\
\text { times } \\
\text { a week }\end{array}$ & $\begin{array}{c}1-\text { a few } \\
\text { times } \\
\text { a month }\end{array}$ & $\begin{array}{c}1-\text { a few } \\
\text { times a } \\
\text { year }\end{array}$ & $\begin{array}{c}\text { occasio- } \\
\text { nally }\end{array}$ & never \\
\hline Food products & $32.8 \%$ & $64.2 \%$ & $2.6 \%$ & - & $0.4 \%$ & - \\
\hline Housewares / RTV & - & - & $5.9 \%$ & $43.8 \%$ & $49.5 \%$ & $0.8 \%$ \\
\hline Clothes & - & $2.2 \%$ & $53.9 \%$ & $37.0 \%$ & $6.9 \%$ & - \\
\hline Underwear & $0.2 \%$ & $0.4 \%$ & $31.5 \%$ & $60.0 \%$ & $7.9 \%$ & - \\
\hline Shoes & - & $0.4 \%$ & $6.1 \%$ & $81.9 \%$ & $11.6 \%$ & - \\
\hline Bags/handbags & - & $0.2 \%$ & $2.3 \%$ & $45.3 \%$ & $46.1 \%$ & $6.1 \%$ \\
\hline Books & - & $1.0 \%$ & $14.5 \%$ & $40.5 \%$ & $38.7 \%$ & $5.3 \%$ \\
\hline Jewellery & - & $0.2 \%$ & $1.8 \%$ & $30.1 \%$ & $61.6 \%$ & $6.3 \%$ \\
\hline Medication & $0.2 \%$ & $2.4 \%$ & $38.6 \%$ & $35.5 \%$ & $22.7 \%$ & $0.6 \%$ \\
\hline Domestic detergents & - & $5.9 \%$ & $68.0 \%$ & $19.0 \%$ & $5.3 \%$ & $1.8 \%$ \\
\hline Cosmetics & - & $4.1 \%$ & $67.0 \%$ & $23.2 \%$ & $4.5 \%$ & $1.2 \%$ \\
\hline
\end{tabular}

Source: own elaboration based on data from the survey.

TABLE 2

The percentage structure of selected places for the purchase of the analyzed groups of goods

\begin{tabular}{|c|c|c|c|c|c|c|}
\hline \multirow[b]{2}{*}{ Groups of goods } & \multicolumn{6}{|c|}{ Shopping place $\left(\mathrm{X}_{\mathrm{B}}\right)$} \\
\hline & > & 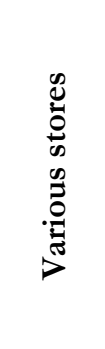 & 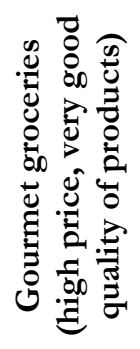 & 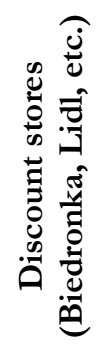 & 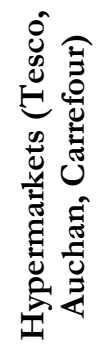 & 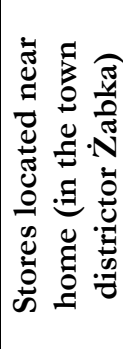 \\
\hline Bakery products & $5.5 \%$ & $10.1 \%$ & $8.3 \%$ & $33.7 \%$ & $3.2 \%$ & $33.3 \%$ \\
\hline Cold meats & $7.9 \%$ & $7.9 \%$ & $18.7 \%$ & $21.1 \%$ & $6.7 \%$ & $22.7 \%$ \\
\hline Sweets & $0.2 \%$ & $9.9 \%$ & $1.6 \%$ & $54.2 \%$ & $15.4 \%$ & $12.0 \%$ \\
\hline Dairy products & $4.9 \%$ & $9.7 \%$ & $5.1 \%$ & $49.9 \%$ & $11.4 \%$ & $14.0 \%$ \\
\hline Vegetables and fruits & $12.2 \%$ & $9.5 \%$ & $3.0 \%$ & $46.0 \%$ & $8.1 \%$ & $15.2 \%$ \\
\hline Sweet baked products & $3.7 \%$ & $11.8 \%$ & $8.5 \%$ & $39.4 \%$ & $11.0 \%$ & $11.8 \%$ \\
\hline Coffee / tea & $1.6 \%$ & $8.3 \%$ & $2.6 \%$ & $55.0 \%$ & $19.1 \%$ & $5.7 \%$ \\
\hline
\end{tabular}

Source: own elaboration based on the research results. 
TABLE 3

The results of independence tests (p-value) for the qualitative variables $\mathrm{X}_{\mathrm{A}}$ - the frequency of purchases of selected groups of goods and $\mathrm{Y}$ - the selected determinants of consumers' behaviors

\begin{tabular}{|c|c|c|c|c|c|}
\hline \multirow[b]{2}{*}{$\begin{array}{l}\text { The frequency of the } \\
\text { purchases of selected } \\
\text { groups of goods }\end{array}$} & \multicolumn{5}{|c|}{ Selected determinants $^{a}(\mathrm{Y})$} \\
\hline & $\begin{array}{l}Y_{1}- \\
\text { age }\end{array}$ & $\begin{array}{c}\mathrm{Y}_{2}-\text { the } \\
\text { number } \\
\text { of persons } \\
\text { in a house- } \\
\text { hold }\end{array}$ & $\begin{array}{c}Y_{3}-\text { the } \\
\text { character } \\
\text { of the lo- } \\
\text { cation/ } \\
\text { place }\end{array}$ & $\begin{array}{l}\mathrm{Y}_{4}- \\
\text { voivo- } \\
\text { deship }\end{array}$ & $\begin{array}{c}\mathrm{Y}_{5}- \\
\text { average } \\
\text { monthly } \\
\text { expendi- } \\
\text { tures on } \\
\text { shopping }\end{array}$ \\
\hline $\mathrm{X}_{\mathrm{A} 1}-$ food products & 0.427 & 0.887 & 0.716 & 0.435 & 0.952 \\
\hline $\mathrm{X}_{\mathrm{A} 2}-$ housewares / RTV & 0.099 & 0.322 & 0.335 & 0.162 & 0.450 \\
\hline $\mathrm{X}_{\mathrm{A} 3}$ - clothes & 0.003 & 0.918 & 0.340 & 0.491 & 0.253 \\
\hline $\mathrm{X}_{\mathrm{A} 4}-$ underwear & 0.119 & 0.731 & 0.148 & 0.268 & 0.880 \\
\hline $\mathrm{X}_{\mathrm{A} 5}-$ shoes & 0.390 & 0.458 & 0.098 & 0.650 & 0.130 \\
\hline $\mathrm{X}_{\mathrm{A} 6}$ - bags / handbags & 0.161 & 0.903 & $0.012^{*}$ & 0.920 & 0.857 \\
\hline $\mathrm{X}_{\mathrm{A} 7}-$ books & $0.017 *$ & 0.535 & $0.001 *$ & 0.643 & 0.120 \\
\hline $\mathrm{X}_{\mathrm{A} 8}-$ jewelry & 0.785 & 0.155 & 0.137 & 0.388 & 0.313 \\
\hline $\mathrm{X}_{\mathrm{A} 9}-$ medication & $0.000^{*}$ & 0.435 & 0.228 & $0.002^{*}$ & 0.867 \\
\hline $\begin{array}{l}\mathrm{X}_{\mathrm{A} 10}-\text { domestic deter- } \\
\text { gents }\end{array}$ & $0.002^{*}$ & $0.002^{*}$ & 0.180 & 0.355 & $0.018^{*}$ \\
\hline $\mathrm{X}_{\mathrm{A} 11}-$ cosmetics & $0.049 *$ & 0.404 & 0.802 & 0.829 & 0.949 \\
\hline
\end{tabular}

a $Y_{1}$ : age groups: less than 24; 25-30; 31-39; 40-49; 50-59; 60-69; 70 and over;

$\mathrm{Y}_{2}: 1,2,3,4$ and 5 or more persons in a household;

$\mathrm{Y}_{3}$ : a village, a Town with: less than 40000 inhabitants,100,000-500,000 inhabitants ; from 41,000 to 100,000 and more than 500,000 inhabitants;

$\mathrm{Y}_{4}$ : voivodeships: Dolnośląskie and Podlaskie

$\mathrm{Y}_{5}$ : the ranges of incomes (in PLN): less than 1000,00; 1000,01-2000,00; 2000,01-3000,00; 3000,01-4000,00; 4000,01-5000,00 and 5000,01 and more.

Statistically significant dependence (at level $\mathrm{p}<0.05$ ) are given in a table *

Source: own elaboration based on data from the survey.

The obtained results of the survey research showed considerable difference in terms of the selection of the place of purchases of particular groups of food products. The most popular shops were discount stores (Biedronka, Lidl, Aldi, Netto, ...), mainly in case of the purchases of coffee/tea, sweets and dairy products. On the other hand, in case of bakery products and cold meats the stores located near home (local stores, Żabka) were as popular as the aforementioned discount stores. Among the analyzed groups of goods bakery products and cold meats were most frequently bought in gourmet groceries (characterized by high prices, but also by the good quality of products) than hypermarkets. For all the analyzed groups of goods very insignificant role was played by both Internet and ecological stores. 
By using statistic tests, attempts were made to solve the following problem: whether there are major statistic differences (at the level of 0.05 ) in terms of the shopping frequency and place depending on the consumer's age, the number of persons in the consumer's household, the place of residence and wealth specified by the average expenses on shopping. Therefore, it was checked whether there is dependence of consumer behaviors on the selected determinants characterizing the respondents.

Tables 3 and 4 present the results of the conducted tests $\chi^{2}$, with the restriction made to only the basic parameter p-value. With the exception of, among others, domestic detergents for all the other groups of goods there was not observed statistically essential dependence between the frequency of shopping and both the number of persons in a household and the average level of expenditures on shopping - relevance level $\mathrm{p}>0.05$ (comp. table 3 ).

TABLE 4

The results of independence tests ( $p$-value) for the quality qualitative variables $X_{B}$ - shopping place of selected groups of goods and $Y$ - selected determinants of consumers' behaviors

\begin{tabular}{|l|c|c|c|c|c|}
\hline \multirow{2}{*}{$\begin{array}{c}\text { Selected groups } \\
\text { of goods }\end{array}$} & \multicolumn{4}{|c|}{ Selected determinants ${ }^{\mathrm{a}}$ (Y) } \\
\cline { 2 - 6 } & $\begin{array}{c}\mathbf{Y}_{1}- \\
\text { age }\end{array}$ & $\begin{array}{c}\mathbf{Y}_{2}-\text { the } \\
\text { number } \\
\text { of persons } \\
\text { in a house- } \\
\text { hold }\end{array}$ & $\begin{array}{c}\mathbf{Y}_{3}-\text { the } \\
\text { character } \\
\text { of the loca- } \\
\text { tion/ } \\
\text { place }\end{array}$ & $\begin{array}{c}\mathbf{Y}_{4}- \\
\text { voivo- } \\
\text { deship } \\
\text { average } \\
\text { monthly } \\
\text { expendi- } \\
\text { tures on } \\
\text { shopping }\end{array}$ \\
\hline $\mathrm{X}_{\mathrm{B} 1-\text { bakery products }}$ & $0.000^{*}$ & 0.628 & 0.453 & $0.015^{*}$ & 0.111 \\
\hline $\mathrm{X}_{\mathrm{B} 2}-$ cold meats & $0.001^{*}$ & $0.000^{*}$ & $0.000^{*}$ & $0.001^{*}$ & $0.010^{*}$ \\
\hline $\mathrm{X}_{\mathrm{B} 3}-$ sweets & $0.000^{*}$ & 0.494 & $0.017^{*}$ & $0.000^{*}$ & 0.052 \\
\hline $\mathrm{X}_{\mathrm{B} 4}-$ dairy products & $0.000^{*}$ & 0.628 & $0.002^{*}$ & $0.002^{*}$ & 0.214 \\
\hline $\mathrm{X}_{\mathrm{B} 5}-$ vegetables and fruits & $0.000^{*}$ & 0.496 & $0.001^{*}$ & $0.011^{*}$ & 0.803 \\
\hline $\begin{array}{l}\mathrm{X}_{\mathrm{B} 6}-\text { sweet baked } \\
\text { products }\end{array}$ & $0.000^{*}$ & $0.016^{*}$ & 0.093 & $0.001^{*}$ & 0.122 \\
\hline $\mathrm{X}_{\mathrm{B} 7}-$ coffee/ tea & $0.000^{*}$ & 0.216 & $0.000^{*}$ & 0.167 & $0.000^{*}$ \\
\hline
\end{tabular}

${ }^{\mathrm{a}}$ comp. table 3 .

Source: own elaboration based on data from the survey.

For the vast majority of groups of consumption goods also the character of the place of residence and the region (whether it is Dolnoślaskie or Podlaskie voivodeship), in statistic terms, had no considerable impact on the shopping frequency.

In terms of the way shopping frequency of such goods as: clothes, books, medication and domestic detergents has changed, there were differences depending on the consumer's age. The dependence level is evaluated by using Yule coefficient $\varphi$ which increased at most by approx. 0.4. 
Slightly different results of statistic tests were obtained for variable $\mathrm{X}_{\mathrm{B}}$ - shopping place (comp. table 4). Namely, in case of all the products there was rejected the hypothesis regarding the equality of structure indicators in accordance with the consumer's age groups, i.e. there occurred statistic dependence of the preference of shopping place on age (especially for cold meats; the coefficient amounted to slightly more than 0.4 ). The selection of shopping place was considerably influence, in statistic terms, by the region of residence - voivodeship (for the majority of groups of goods, with the exception of coffee/ tea), and also the character of the town (for the vast majority of groups of goods, with the exception of bakery products and sweet baked products). On the other hand, in the analysis of the variable the number of persons in a household there was no basis for rejecting the hypothesis regarding the equality of structure indicators, i.e. there were no basis for rejecting the hypothesis regarding the dependence of the purchase place on this variable.

\section{Conclusions}

The conducted research implies that 97\% respondents do shopping at least once a week, as many as 33\% reviewed persons go shopping every day. High frequency results from the need to purchase food products. Polish people purchase domestic detergents a few times a month, clothes, shoes and underwear - a few times a year whereas jewelry - occasionally. The most frequently selected type of retail trade is a discount store where respondents purchased sweets, dairy products, coffee, tea, vegetables and fruits. The conclusion was drawn that respondents select better quality of cold meats, vegetables and fruits in stores that are located near their home but guarantee high quality.

There was observed statistically essential dependence of preferences in terms of the frequency of purchases on the consumer's age (especially in case of medication and clothes) and on the character of the town and the region (in particular, as regards the purchase of cold meats and coffee/tea). The selection of the shopping place was in statistic terms considerably affected by the region of residence - a voivodeship (for most groups of goods with the exception of coffee/tea), and by the character of a town (for the majority of groups of goods, with the exception of bakery products and sweet baked products) or the level of allocated incomes (mainly as regards the purchase of cold meats and coffee/tea).

\section{References}

Aczel A.D., Sounderpandian J., 2017, Statystykea w zarzadzaniu, PWN, Warszawa. Angowski M., Domańska K., 2015, Caynniki wplywajace na wybór miejsca dokonywania zakupu na rynku seróm żóttych na prayłktadzie serón dtugodojrzewajacych, „Zeszyty Naukowe Uniwersytetu Szczecińskiego. Problemy Zarządzania, Finansów i Marketingu", nr 41(2), s. 385-397. 
Anselmsson J., 2006, Sources of customer satisfaction with shopping malls: A comparative study of different customer segments, ,The International Review of Retail, Distribution and Consumer Research", vol. 16(1), pp. 115-138, DOI: 10.1080/0959396050045 3641.

Bell D. R., Corsten D., Knox G., 2011, From Point of Purchase to Path to Purchase: How Preshopping Factors Drive Unplanned Buying, "Journal of Marketing”, vol. 75(1), pp. 31-45, DOI: 10.1509/jmkg.75.1.31.

Carpenter J.M., Moore M., 2006, Consumer Demographics, Store Attributes and Retail Format Choice in the US Grocery Market, „International Journal of Retail and Distribution Management", vol. 34(6), pp. 434-452, DOI: 10.1108/0959055061066 7038.

Caspi C.E., Lenk K., Pelletier J.E., Barnes T.L., Harnack L., Erickson D.J., Laska M.N., 2017, Association between store food environment and customer purchases in small grocery stores, gas-marts, pharmacies and dollar stores, „International Journal of Behavioral Nutrition and Physical Activity", vol. 14(71), DOI: 10.1186/s12966-017-0531-x.

Chmielak A., 2015, Popytowe unvarunkowania konkurencyjności matych $i$ średnich præedsiebiorstw, „Optimum. Studia ekonomiczne”, nr 78(6), s. 72-84, DOI: 10.15290/ose. 2015.06.78.06.

Gensler S., Verhoef P.C., Böhm M., 2012, Understanding consumers' multichannel choices across the different stages of the buying process, „Marketing Letters”, 23(4), pp. 9871003, DOI: $10.1007 /$ s11002-012-9199-9

Hill J.C., 1988, Differences in the consumer decision process for professional vs. Generic services, „Journal of Services Marketing”, vol. 2(1), pp. 17-23, DOI: 10.1108/eb024712.

Jaciow M., Wolny R., Stolecka-Makowska A., 2013, E-konsument w Europie. Komapratywna analzia zachowań. HELION, Gliwice.

Jacobs S., Van Der Merwe D., Lombard E., Kruger N., 2010, Exploring consumers' preferences with regard to department and specialist food stores, „International Journal of Consumer Studies", vol. 34(2), pp. 169-178, DOI: 10.1111/j.1470-6431.2009. 00844.x

Kaczmarczyk S., 2003, Badania marketingowe. Metody i techniki, PWE, Warszawa.

Kamran-Disfani O., Mantrala M.K., Izquierdo-Yusta A., Pilar Martínez-Ruizd M., 2017, The impact of retail store format on the satisfaction-loyalty link: An empirical investigation, „Journal of Business Research”, vol. 77, pp. 14-22, DOI: org/10.1016/j. jbusres.2017.04.004.

Kim J., Lee H-H., 2008, Consumer product search and purchase behaviour using various retail channels: the role of perceived retail usefulness, „International Journal of Consumer Studies", vol. 32(6), pp. 619-627, DOI: 10.1111/j.1470-6431.2008.00689.x.

Kosicka-Górecka M., Tul-Krzyszczuk A., Gębski J., 2011, Handel detaličny ṡywności w Polsce, SGGW, Warszawa.

Mitchell V-W., 1992, Understanding Consumers' Behaviour: Can Perceived Risk Theory Help?, „Management Decision”, vol. 30(3), pp. 26-31, DOI: 10.1108/00251749210013 050, http://pentor-arch.tnsglobal.pl/60303.xml?doc_id=11280 [date of entry: 03.04.2013]. 
Morganosky M.A., Cude B.J., 2000, Large format retailing in the US: a consumer experience perspective, „Journal of Retailing and Consumer Services”, vol. 7(4), pp. 215-222, DOI: 10.1016/S0969-6989(00)00016-3.

Nilsson E., Gärling T., Marell A., 2017, Effects of time pressure, shopping type, and store attributes on consumers' satisfaction with grocery shopping, "The International Review of Retail, Distribution and Consumer Research", vol. 27(4), pp. 334-351, DOI: 10.1080/09593969.2017.1309674.

Rajagopal, 2011, Determinants of Shopping Behavior of Urban Consumers, Journal of International Consumer Marketing, vol. 23(2), pp. 83-104, DOI: 10.1080/08961530. 2011.543051.

Ruff R.R., Akhund A., Adjoian T., 2016, Small Convenience Stores and the Local Food Environment: An Analysis of Resident Shopping Behavior Using Multilevel Modeling, „American Journal of Health Promotion”, vol. 30(3), pp. 172-180, DOI: 10.4278/ajhp.140326-QUAN-121.

Sunelle J., xan Der Merwe D., Lombard E., Kruger N., 2010, Exploring consumers' preferences with regard to department and specialist food stores, „International Journal of Consumer Studies", vol. 34(2), pp. 169-178, DOI: 10.1111/j.1470-6431.2009. 00844.x.

Szreder M., 2010, Metody i techniki sondażonych badań opinii, PWE, Warszawa.

Szwacka-Salmonowicz J.E., 2003, Zmiany zachowań nabywców jako determinanta ksztaltowania strategii segmentacyjnych przedsiebiorstw przemystu sposiywczego w Polsce, SDDW, Warszawa.

Urban S., Michałowska M., 2013, Determinanty wyboru konsumentón dotyczace miejsca zakupu. Raport z badań, „Nauki o Zarządzaniu Management Sciences”, t. 3(16), s. $133-153$.

Urban S., Michałowska M., 2013a, Czynniki wplywajace na zachowania konsumentów w zakeresie wyboru targowisk jako miejsca zakupu produktón konsumpcyjnych na praylktadzie województwa lubuskiego, „Roczniki Ekonomiki Rolnictwa i Rozwoju Obszarów Wiejskich", vol. 100(2), s. 108-118.

Wel Ch., Hussin S.R., Omar N.A., Nor S.M., 2012, Important determinant of consumers' retail selection decision in Malaysia, „World Review of Business Research”, vol. 2(2), pp. 164-175.

Zachowania zakupowe Polaków 2010, 2010, Pentor Research International, http://pentor-arch.tnsglobal.pl/60303.xml?doc_id=11280 [date of entry: 03.04.2016]. 